\title{
Osteomuscular disorders and associated factors among solid waste collectors of two middle-sized cities from the South of Brazil*
}

\author{
Distúrbios osteomusculares e fatores associados em coletores de lixo de duas cidades de \\ porte médio do sul do Brasil
}

Rodrigo Kohn Cardoso ${ }^{1}$, Airton José Rombaldi ${ }^{1}$, Marcelo Cozzensa da Silva ${ }^{1}$

${ }^{*}$ Received from Federal Univeristy of Pelotas, Pelotas, $R S$, Brazil.

DOI 10.5935/1806-0013.20140004

\section{ABSTRACT}

BACKGROUND AND OBJECTIVES: Solid waste collectors are constantly exposed to high physical demands and precarious ergonomic conditions at work. This study aimed to identify the prevalence of osteomuscular disorders and associated factors among solid waste collectors of two middle-sized cities from Southern Brazil.

METHODS: This was an observational cross-sectional census study. Population was made up of all solid waste collectors of the cities of Pelotas and Rio Grande, RS. Data were collected through a questionnaire with sociodemographic, economic, nutritional and behavioral variables. Prevalence of osteomuscular disorders was evaluated with the Nordic Questionnaire for Osteomuscular Symptoms.

RESULTS: All 127 solid waste collectors were interviewed. Prevalence of osteomuscular disorders in the last 12 months was $88.2 \%$. Among affected workers, $94.5 \%$ reported no pain before starting collecting solid waste. Most affected body regions were legs, knees and lumbar spine, respectively. After multivariate analysis, only body mass index remained associated to osteomuscular disorders. CONCLUSION: The prevalence of osteomuscular symptoms among solid waste collectors in Southern of Brazil is high. Adequate prevention strategies are needed.

Keywords: Cumulative traumatic disorders, Occupational diseases, Occupational health, Solid waste collection, Workers.

\section{RESUMO}

JUSTIFICATIVA E OBJETIVOS: Os coletores de lixo estão constantemente expostos a alta exigência física e condiçóes er-

1. Federal University of Pelotas, Pelotas, RS, Brazil.

Submitted in September 12, 2013.

Accepted for publication in February 11, 2014.

Conflict of interests: None.

Correspondence to:

Marcelo Cozzensa da Silva

Rua Luis de Camôes, 625

96055-630 Pelotas, RS, Brasil.

E-mail: cozzensa@terra.com.br

(๑) Sociedade Brasileira para o Estudo da Dor gonômicas precárias no trabalho. O objetivo deste estudo foi verificar a prevalência de distúrbios osteomusculares e fatores associados em coletores de lixo de duas cidades de porte médio do sul do Brasil.

MÉTODOS: Este estudo caracterizou-se como observacional transversal do tipo censo. A populaçáo foi composta por todos os coletores de lixo das cidades de Pelotas e Rio Grande, RS. A coleta de dados foi realizada por meio de um questionário contendo questôes relativas a variáveis sociodemográficas, econômicas, nutricionais e comportamentais. A prevalência de distúrbios osteomusculares foi avaliada através do Questionário Nórdico de Sintomas Osteomusculares.

RESULTADOS: Foram entrevistados todos os 127 coletores de lixo. A prevalência de distúrbios osteomusculares nos últimos 12 meses foi de 88,2\%. Dentre os trabalhadores acometidos, 94,5\% não apresentavam qualquer dor antes de exercerem a atividade de coleta de lixo. As regióes do corpo mais acometidas foram pernas, joelhos e coluna lombar, respectivamente. Após análise multivariável apenas o índice de massa corpórea permaneceu associado aos distúrbios osteomusculares.

CONCLUSÁO: A prevalência de sintomas osteomusculares entre coletores de lixo do sul do Brasil é alta. Estratégias adequadas de prevenção são necessárias.

Descritores: Coleta de resíduos sólidos, Doenças profissionais, Saúde ocupacional, Trabalhadores, Transtornos traumáticos cumulativos.

\section{INTRODUCTION}

Solid waste collectors, popularly called street sweepers and/or dustmen, are responsible for a public service essential for environmental preservation, thus for public health: collecting household and commercial waste. It is estimated that more than 90 thousand people perform this work in Brazil ${ }^{1}$ and during their labor activity they are exposed to physical, chemical, biological and psycho-social risks ${ }^{2}$. Solid waste collectors have a high workload, with intensive physical demands, among them walking, running, going up and down slopes and raising and carrying weight along the day, among others ${ }^{1}$.

Exposure to high physical demand levels may trigger damages to health such as onset of osteomuscular symptoms, technically called Work-Related Musculoskeletal Disorders (WMSDs) ${ }^{3}$. According to the Department of Health, WMSDs are musculoskel- 
etal injuries caused by excessive use of such structures, associated to insufficient recovery. They are characterized by symptoms as pain, paresthesia, sensation of weight and fatigue, simultaneously or not. They involve clinical presentations of the musculoskeletal system acquired by workers submitted to certain working conditions ${ }^{4}$.

In the United States, WMSDs are responsible for more than half the diseases benefited by the Workers Compensation Insurance ${ }^{5}$ and in Brazil, 48.2\% of social security benefits granted in 2006 were a consequence of such morbitities ${ }^{6}$. According to the Workers' Health Information System, 51.2\% of reported diseases in 2008 in the state of Rio Grande do Sul, state from the extreme South of Brazil, were WMSDs. So, it is clear that WMSDs are a public health problem.

There are few published studies evaluating osteomuscular health of solid waste collectors around the world. A study evaluating waste collection-related factors has observed that only $3 \%$ of such studies have investigated osteomuscular injuries ${ }^{7}$. A different study carried out in Florida, USA, has found $75 \%$ prevalence of osteomuscular injuries in the last 12 months among household solid waste collectors ${ }^{8}$. In Brazil, few studies were found analyzing such subject.

In light of the severity of the problem involving workers' health, as well as due to a gap in the knowledge about the prevalence of osteomuscular disorders among solid waste collectors, this study is justified and aims at investigating the prevalence of osteomuscular disorders among solid waste collectors of two middle-sized cities of the extreme South of Brazil.

\section{METHODS}

This observational transversal census study was carried out in the cities of Pelotas and Rio Grande. Pelotas is a city with 328,864 inhabitants and, according to Pelotas Autonomous Sanitation Service (SANEP), approximately 160 tons of solid waste are collected every day in the urban zone of the city. Rio Grande has 198,048 inhabitants and produces approximately 130 tons of solid waste every day, according to the Municipal Department of Urban Services.

Information was collected via a questionnaire with 50 questions, to evaluate sociodemographic characteristics (education in years of study, marital status, skin color); economic characteristics (economic level, with the Brazilian Association of Research Companies (ABEP) tool, and family income in reals); behavioral characteristics (smoking and drinking) with the CAGE questionnaire, made up of four questions related to the anagram Cut down, Annoyed by criticism, Guilty and Eye-opener (have you ever felt that you should decrease the amount of alcoholic drinks or quit drinking?). Cut down; do people annoy you because they criticize the way you drink alcoholic beverages? Annoyed by criticism; do you feel annoyed with yourself by the way you drink alcoholic beverages? Guilty; do you drink alcohol in the morning to decrease nervousness or hangover? Eye-opener; anthropometric (selfreported weight and height); working characteristics (work- ing time in months and daily workload in hours). Outcome, prevalence of osteomuscular disorders in the last 12 months, was evaluated with the Nordic Osteomuscular Symptoms Questionnaire (NOSQ), which is a tool to measure the presence of symptoms in different anatomic regions, validated in Brazil in 2002 by Pinheiro, Tróccolia and Carvalho?.

Questionnaires were applied by interviewers who went through a 12-hour training program where questions regarding interview techniques, questionnaire knowledge and interview simulation were addressed. Interviews lasted approximately 30 minutes. Quality control was performed by the chief-researcher by reapplying a questionnaire with five key-questions to $5 \%$ of workers of each city.

Questionnaires were entered twice in the program EPIDATA 3.1. Program STATA 10.0 was used for statistical analysis. Multivariate analysis was performed for all collected data, with calculation of central trend and dispersion to describe continuous variables, and proportion measurements for categorical variables. Chi-square and linear tests were used to check the association between outcome and predictors being studied. Poisson Regression was used to analyze the association between independent variables and controlled outcomes for possible confounders. Confidence level established for the study was $\mathrm{p}<0.05$.

This study was approved by the Research Ethics Committee, Superior School of Physical Education, Federal University of Pelotas, under n. 003/2011.

The consent of the committee was obtained prior to data collection. Ethical principles were assured to companies and employees, so that all have agreed to participate in the study and have signed the Free and Informed Consent Term.

\section{RESULTS}

All 127 solid waste collectors, all males and working for the company in charge of waste collection in the studied cities were interviewed during the month of December 2011, being active or not (vacations and/or medical leave). Most individuals were non-Caucasians (57.5\%), married/lived with companion $(70.1 \%)$, mean age and education, respectively, $26.2 \pm 5.4$ years, varying from 18 to 45 years of age, and $6.2 \pm 2.33$ years of education. According to ABEP, $80 \%$ of workers belonged to economic level C, and 55.9\% worked with the company for a period equal to or less than one year. According to body mass index (BMI), 80\% of workers were classified as normal. Thirty-four percent have reported smoking and $15.1 \%$ showed indicators for alcoholism. There have been no losses or refusals for the study. Table 1 shows sociodemographic, economic, nutritional and behavioral description of the population.

A total of 112 workers (88.2\%) have reported some type of pain or osteomuscular discomfort in one or more body regions in the last year. Important information to be described is that, from all collectors, $94.5 \%$ have reported no musculoskeletal pain before starting the collection work.

Stratified analysis by city has shown that the prevalence of 
Table 1. Prevalence of sociodemographic, economic, nutritional and behavioral variables and work characteristics of solid waste collectors of the cities of Pelotas and Rio Grande/RS, $2013(n=127)$

\begin{tabular}{|c|c|}
\hline Variables & $\begin{array}{c}\text { Prevalence } \\
\mathrm{n}(\%)\end{array}$ \\
\hline $\begin{array}{l}\text { Age (years) } \\
\qquad \begin{array}{l}18-21 \\
22-25 \\
26-29 \\
30 \text { or above }\end{array}\end{array}$ & $\begin{array}{l}26(20.5) \\
39(30.7) \\
29(22.8) \\
33(26.0)\end{array}$ \\
\hline $\begin{array}{l}\text { Skin color } \\
\text { Caucasian } \\
\text { Non Caucasian }\end{array}$ & $\begin{array}{l}54(42.5) \\
73(57.5)\end{array}$ \\
\hline $\begin{array}{l}\text { Education } \\
\text { Incomplete elementary } \\
\text { Complete elementary } \\
\text { High school } \\
\text { Incomplete university }\end{array}$ & $\begin{array}{c}87(68.5) \\
23(18.1) \\
15(11.8) \\
2(1.6)\end{array}$ \\
\hline $\begin{array}{l}\text { Economic class } \\
\text { B } \\
\text { C } \\
\text { A }\end{array}$ & $\begin{array}{c}11(8.7) \\
96(75.6) \\
20(15.7)\end{array}$ \\
\hline $\begin{array}{l}\text { Marital situation } \\
\text { Married/with companion } \\
\text { Single/without companion }\end{array}$ & $\begin{array}{l}89(70.1) \\
38(29.9)\end{array}$ \\
\hline $\begin{array}{l}\text { Smoking } \\
\text { Never smoked } \\
\text { Former smoker } \\
\text { Smoker }\end{array}$ & $\begin{array}{l}66(52.0) \\
18(14.0) \\
43(34.0)\end{array}$ \\
\hline $\begin{array}{l}\text { Indicative for alcoholism (CAGE } \\
\text { Negative } \\
\text { Positive }\end{array}$ & $\begin{array}{c}107(84.9) \\
19(15.1)\end{array}$ \\
\hline $\begin{array}{l}\text { Body mass index }\left(\mathrm{kg} / \mathrm{m}^{2}\right) \\
\text { Normal } \\
\text { Overweight/obesity }\end{array}$ & $\begin{array}{c}103(81.7) \\
24(18.3)\end{array}$ \\
\hline $\begin{array}{l}\text { Working time (months) } \\
\text { Less than } 1 \\
1-12 \\
13-60 \\
\text { More than } 60\end{array}$ & $\begin{array}{l}22(17.3) \\
49(38.6) \\
38(29.9) \\
18(14.2)\end{array}$ \\
\hline
\end{tabular}

pain in at least one body region in the last 12 months was, respectively, in Pelotas and Rio Grande, 85.5 and 92.2\%. When studying those workers in such function for up to one year and with no pain before starting it, $81.8 \%$ in Pelotas and $93.7 \%$ in Rio Grande were affected by pain.

With regard to work shift, individuals working in the evenings had $91.1 \%$ prevalence of osteomuscular disorders, followed by $85.3 \%$ among those working during the day. Most affected body regions were, respectively, legs (40.9\%), knees (36.2\%), lumbar region (35.4\%) and thoracic spine $(34.7 \%)$ (Figure 1).

In the bivariate analysis, variables skin color, age, education, economic class, smoking, marital status, work shift and working time were not associated with WRODs. Only alcohol ingestion and BMI (related to overweight/obesity) were identified as factors associated with osteomuscular disorders. In the multivariate analysis, only BMI has remained associated with osteomuscular disorders (Table 2).

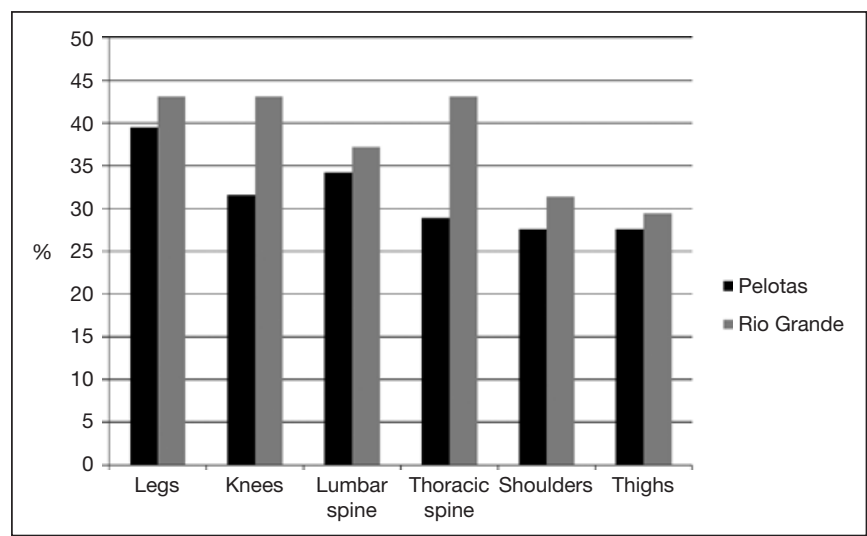

Figure 1. Prevalence of body regions most affected by osteomuscular disorders in the last 12 months among solid waste collectors of the cities of Pelotas and Rio Grande/RS, 2013 ( $n=127)$

Table 2. Gross and adjusted analysis of the association between osteomuscular disorders and predictors among solid waste collectors of Pelotas and Rio Grande/RS, $2013(n=127)$

\begin{tabular}{|c|c|c|c|c|}
\hline \multirow[b]{2}{*}{ Variables } & \multicolumn{2}{|c|}{ Gross analysis } & \multicolumn{2}{|c|}{ Adjusted analysis } \\
\hline & $\begin{array}{l}\text { Muscle } \\
\text { disorders } \\
(\%)\end{array}$ & $\begin{array}{c}\mathrm{p} \\
\text { value }\end{array}$ & PR (Cl 95\%) & $\begin{array}{c}\mathrm{p} \\
\text { value }\end{array}$ \\
\hline Skin color & & $0.44^{*}$ & & 0.46 \\
\hline $\begin{array}{l}\text { Caucasian } \\
\text { Non Caucasian }\end{array}$ & $\begin{array}{l}90.7 \\
86.3\end{array}$ & & $\begin{array}{c}1.0 \\
0.9(0.8-1.1)\end{array}$ & \\
\hline $\begin{array}{l}\text { Age (years) } \\
\text { Up to } 21 \\
22-25 \\
26-29 \\
30 \text { above }\end{array}$ & $\begin{array}{c}88.5 \\
87.2 \\
100.0 \\
78.8\end{array}$ & $0.05^{\star \star}$ & $\begin{array}{c}1.0 \\
1.0(0.8-1.2) \\
1.1(1.0-1.3) \\
0.9(0.8-1.1)\end{array}$ & 0.60 \\
\hline $\begin{array}{l}\text { Marital status } \\
\text { With companion } \\
\text { Without companion }\end{array}$ & $\begin{array}{l}88.8 \\
86.8\end{array}$ & $0.76^{\star \star}$ & $\begin{array}{c}1.0 \\
0.8(0.8-1.1)\end{array}$ & 0.80 \\
\hline $\begin{array}{l}\text { Education (years) } \\
\text { Up to } 4 \\
5-8 \\
9 \text { or more }\end{array}$ & $\begin{array}{l}80.7 \\
91.1 \\
88.2\end{array}$ & $0.34^{\star \star}$ & $\begin{array}{c}1.0 \\
1.1(0.9-1.3) \\
1.1(0.8-1.4)\end{array}$ & 0.50 \\
\hline $\begin{array}{l}\text { Economic class } \\
\text { B } \\
\text { C } \\
\text { D }\end{array}$ & $\begin{array}{c}100.0 \\
88.8 \\
83.3\end{array}$ & $0.20^{\star \star}$ & $\begin{array}{c}1.0 \\
1.0(0.8-1.2) \\
1.2(1.0-1.3)\end{array}$ & 0.20 \\
\hline $\begin{array}{l}\text { Smoking } \\
\text { Non smoker } \\
\text { Smoker }\end{array}$ & $\begin{array}{l}85.7 \\
93.0\end{array}$ & $0.26^{\star \star}$ & $\begin{array}{c}1.0 \\
1.1(1.0-1.2)\end{array}$ & 0.20 \\
\hline $\begin{array}{l}\text { Alcohol ingestion } \\
\text { Yes } \\
\text { No }\end{array}$ & $\begin{array}{l}91.8 \\
83.0\end{array}$ & $0.13^{*}$ & $\begin{array}{c}1.0 \\
1.1(1.0-1.3)\end{array}$ & 0.20 \\
\hline $\begin{array}{l}\text { Body mass index } \\
\text { Normal weight } \\
\text { Overweight/obese }\end{array}$ & $\begin{array}{l}85.4 \\
95.8\end{array}$ & $0.05^{\star \star}$ & $\begin{array}{c}1.0 \\
1.1(1.1-1.2)\end{array}$ & 0.05 \\
\hline $\begin{array}{l}\text { Work shift } \\
\text { Day } \\
\text { Evening }\end{array}$ & $\begin{array}{l}85.3 \\
91.1\end{array}$ & $0.41^{\star \star}$ & $\begin{array}{c}1.0 \\
1.1(0.9-1.2)\end{array}$ & 0.23 \\
\hline $\begin{array}{l}\text { Working } \\
\text { (months) }\end{array}$ & & $0.60^{\star *}$ & & 0.28 \\
\hline $\begin{array}{l}\text { Less than } 1 \\
1-12 \\
13-24 \\
25-48 \\
49 \text { or more }\end{array}$ & $\begin{array}{c}90.9 \\
87.8 \\
94.7 \\
100.0 \\
75.0\end{array}$ & & $\begin{array}{c}1.0 \\
0.9(0.8-1.1) \\
1.1(0.9-1.3) \\
1.1(0.9-1.3) \\
0.8(0.6-1.1)\end{array}$ & \\
\hline
\end{tabular}




\section{DISCUSSION}

The problem of osteomuscular injuries affecting workers has been widely described in most different jobs. Studies describing the prevalence of WMSDs among solid waste collectors were carried out in several countries, such as Egypt ${ }^{10}$, United States ${ }^{11}$ and Taiwan ${ }^{12}$, among others. However, few studies were found on solid waste collectors in Brazil.

The prevalence of osteomuscular symptoms found in this study among solid waste collectors in the last 12 months $(88.2 \%)$ was higher than that described for other regions of the world for this same population ${ }^{8,10,13}$. A study ${ }^{10}$ has found $60.8 \%$ of osteomuscular disorders among solid waste collectors of Mansoura, Egypt $^{10}$, while Mehrdad et al. ${ }^{13}$ have reported $65 \%$ of disorders among solid waste collectors from Tehran. The high prevalence found in our study may be explained by the way solid waste is collected, which is still predominantly manual, as in most developing countries ${ }^{10}$. Another factor which may contribute for these findings is the workload this population is subject to, in average 8.5 hours. In days with high volume of waste this workload, according to collectors, gets close to 14 hours, which is the case of Mondays and after holidays.

Differently from other studies with solid waste collectors ${ }^{10,13}$, legs and knees were the most prevalent sites for musculoskeletal symptoms among the participants of this study. The excess of repetitive movements and load during work, running and crouching, as well as constant jumps to go up and down the truck may be major factors responsible for such prevalence. In addition, footware used (boots without a good damping system) during work may possibly be one more factor contributing to the high number of reports on legs and knees pain.

Another very affected region was the lumbar spine. More than one third of the workers have reported pain in this region, data which are in line with findings of other studies with this population $^{10,12,13}$. Authors have highlighted as possible factors associated with prevalence of low back pain the performance of repetitive movements, lifting and carrying loads, flexions, turns, vibration and high physical demand during work ${ }^{14}$, factors which are part of solid waste collection routine.

Variables skin color, education, economic class, smoking, alcohol ingestion, marital status, work shift and working time were not associated with osteomuscular disorders in the bivariate analysis. In multivariate analysis, age has lost association with outcome, remaining just BMI related to it. The association of BMI and osteomuscular disorders has been shown in previous studies with different populations ${ }^{15}$. High BMI is added to the exposure to physiological loads, favoring the onset of musculoskeletal problems. These data indicate that increased BMI also increases vulnerability to osteomuscular disorders, since by overloading musculoskeletal structures it may induce pain, especially in knees and lumbar spine ${ }^{16}$.

Some limitations of this study have to be reported. Remembrance time of 12 months to determine the prevalence of osteomuscular symptoms may lead to underestimation of values found due to the difficulty to remember the fact, especially if pain was mild. As other studies with workers, healthy workers' bias cannot be overlooked. However, the way the questionnaire was applied, by well-trained interviewers, with special attention to variables involving remembrance time, as well as the fact that all solid waste collectors were interviewed, including those on medical leave, leads us to believe that collected data reflect the reality of the prevalence of osteomuscular symptoms among these workers. In addition, the lack of losses and refusals, which has been result of an effective logistics, and the novelty of this type of study in the Southern region of Brazil, are points to be highlighted in this study.

\section{CONCLUSION}

The prevalence of osteomuscular symptoms among solid waste collectors in the Southern region of Rio Grande do Sul is high, and the same is true for developed countries. So, we suggest the implementation of adequate prevention strategies, such as the use of footwear with better damping system, the introduction of educative programs on postures and less aggressive movements for the body, as well as the development of programs aiming at preparing, compensating and relaxing individuals before, during and after work, such as labor gymnastic.

\section{REFERENCES}

1. Anjos LA, Ferreira JA, Damiáo JJ. Heart rate and energy expenditure during garbage collection in Rio de Janeiro, Brazil. Cad Saude Publica. 2007;23(11):2749-55.

2. Porta D, Milani S, Lazzarino AI, Perucci CA, Forastiere F. Systematic review of epidemiological studies on health effects associated with management of solid waste. Environ Health. 2009;8:60.

3. Gelberg KH. Health study of New York City department of Sanitation landfill employees. J Occup Environ Med. 1997;39(11):1103-10.

4. Maeno M, Salerno V, Rossi DG, Fuller R. Lesōes por esforços repetitivos (LER) Distúrbios osteomusculares relacionados ao trabalho (DORT): Dor relacionada ao trabalho. Ministério da Saúde. Brasília; 2006. Disponível em http://bvsms.saude.gov.br/ bvs/publicacoes/protocolo_ler_dort.pdf. Acessado em 25 de novembro de 2013.

5. Leigh JP, Robbins JA. Occupational disease and workers compensation: coverage, costs, and consequences. Milbank Q. 2004;82(4):689-721.

6. Souza NS, Santana VS. Cumulative annual incidence of disabling work-related musculoskeletal disorders in an urban area of Brazil. Cad Saude Publica. 2011;27(11):2124-34.

7. Kuijer PP, Sluiter JK, Frings-Dresen MH. Health and safety in waste collection: towards evidence-based worker health surveillance. Am J Ind Med. 2010;53(10):1040-64.

8. Englehardt JD, An H, Fleming LE, Bean JA. Analytical predictive Bayesian assessment of occupational injury risk: municipal solid waste collectors. Risk Anal. 2003;23(5):917-27.

9. Pinheiro FA, Tróccolia, BT, Carvalho CV. Validação do questionário nórdico de sintomas osteomusculares como medida de morbidade. Rev Saúde Pública. 2002;36(3):307-12.

10. Abou-Elwafa HS, El-Bestar SF, El-Gilany AH, Awad Eel-S. Musculoskeletal disorders among municipal solid waste collectors in Mansoura, Egypt: a cross-sectional study. BMJ Open. 2012;2(5) pii:e001338.

11. Dorevitch S, Marder D. Occupational hazards of municipal solid waste workers. Occup Med. 2001;16(1):125-33.

12. Yang CY, Chang WT, Chuang HY, Tsai SS, Wu TN, Sung FC. Adverse health effects among household waste collectors in Taiwan. Environ Res. 2001;85(3):195-9.

13. Mehrdad R, Majlessi-Nasr M, Aminian O, Sharifian SA, Malekahmadi F. Musculoskeletal disorders among municipal solid waste workers. Acta Med Iran. 2008;46(3):233-8.

14. da Silva MC, Fassa AG, Kriebel D. Musculoskeletal disorders among ragpickers in a southern city in Brazil. Am J Ind Med. 2006;49(5):327-36.

15. Bodin J, Ha C, Sérazin C, Descatha A, Leclerc A, Goldberg M, et al. Effects of individual and work-related factors on incidence of shoulder pain in a large working population. J Occup Health. 2012;54(4):278-88.

16. Sapia T, Felli VE, Ciampone MH. Health problems among outpatient nursing personnel with a high physiological workload. Acta Paul Enferm. 2009;22(6):808-13. 